\title{
Investigating the writing quality of students with different proficiency levels in interaction-based pair works
}

\author{
Erlik Widiyani Styati ${ }^{*}$ and Rojab Siti Rodliyah ${ }^{2}$ \\ ${ }^{I}$ Department of English Language Teaching, Faculty Teacher Training and Education, \\ Universitas PGRI Madiun, Jl. Setiabudi No. 85, Madiun, East Java, Indonesia \\ ${ }^{2}$ English Education Study Program, Faculty of Language and Literature Education, \\ Universitas Pendidikan Indonesia, Jl. Dr. Setiabudhi No. 229, Bandung West Java, Indonesia
}

\begin{tabular}{|c|c|c|}
\hline \multirow{2}{*}{\multicolumn{3}{|c|}{$\begin{array}{l}\text { ABSTRACT } \\
\text { Pair work, an activity involving learners working together in pairs, has been widely used in } \\
\text { language learning, especially in writing classes. Many studies have reported the effectiveness of } \\
\text { this technique in improving students' writing. However, there is limited research on how the } \\
\text { factors like students' proficiency and the level of interaction may affect the effectiveness of pair } \\
\text { work. Proficiency and interaction between students are important in writing activities because } \\
\text { when students are proficient and given a chance to interact, communicate and collaborate with } \\
\text { others, they tend to produce a good writing as a result of their collaboration. This study, } \\
\text { therefore, aims at investigating whether or not there is a significant difference in students' } \\
\text { writing (1) between the high proficient students engaging in the dominant-dominant pairs (H- } \\
\text { DDP) and those engaging in the dominant-passive pairs (H-DPP), and (2) between the low } \\
\text { proficient students engaging in the dominant-dominant pairs (L-DDP) and those engaging in the } \\
\text { dominant-passive pairs (L-DPP). This experimental research involved forty-eight fourth } \\
\text { semester students of an English Education Department in a private university in Madiun, East } \\
\text { Java, Indonesia as participants. The data were obtained from the students' writing test and } \\
\text { analysed using independent t-test of SPSS } 18.0 \text { version. The results show that the high } \\
\text { proficient students engaging in the dominant-dominant pairs (H-DDP) gained better score in the } \\
\text { aspects of content (26.50 } 24.82 \text { ), organization (19.71 > } 19.09 \text { ), vocabulary (15.36 }>14.09 \text { ) } \\
\text { and grammar (13.43 > } 12.73 \text { ) on argumentative essay than the high proficient students in the } \\
\text { dominant-passive pairs (H-DPP). Meanwhile, the low proficient students engaging in DDP can } \\
\text { write better in the aspects of organization, vocabulary and mechanics. It is also found that } \\
\text { proficiency affects the students' ability to work in pair and to actively contribute to the process } \\
\text { of writing an argumentative essay. This implies that teachers should consider students' } \\
\text { proficiency and level of social interaction before assigning students into pairs in writing classes. } \\
\text { Keywords: Argumentative essay; dominant pair work; passive pair work; proficiency; writing }\end{array}$}} \\
\hline & & \\
\hline & & \\
\hline \multicolumn{3}{|c|}{$\begin{array}{l}\text { How to cite (in APA style): } \\
\text { Styati, E. W. \& Rodliyah, R. S. (2021). Investigating the writing quality of students with } \\
\quad \text { different proficiency levels in interaction-based pair works. Indonesian Journal of Applied } \\
\quad \text { Linguistics, } 11(1), 39-48 . \text { https://doi.org/10.17509/ijal.v11i1.34659 }\end{array}$} \\
\hline
\end{tabular}

\section{INTRODUCTION}

Many studies have been conducted in the area of writing skills as the second and foreign language. Chen's (2002) study, for example, found that from students' view, EFL writing problems ranged from the inability of using words properly, the insufficient vocabulary, the serious difficulty in grammar, and the students' different perception of English organization from L1. Consequently, writing is regarded as the most demanding language

\footnotetext{
*Corresponding Author

Email: erlikwidiyani@unipma.ac.id
} 
skill to learn since it requires a higher level of productive language control than the other skills so that many students think it problematic to write a text because they lack of vocabulary, grammar, mechanics, and punctuation. In line with this, Barkaoui (2007) found that L2 writing is considered as the most challenging skill because it requires the learners to learn a variety of linguistic skills and to gain cognitive and socio-cultural competencies. Therefore, L2 learners find it difficult because they need not only to acquire the knowledge about the features of the texts with good structure/organization and have adequate vocabulary, but also need to be able to apply various writing strategies, as well as ability to consider the context and the audiences of the target community. Additionally, Adeyemi (2012) reports in her study that the students consider English writing demanding because they lack of vocabulary, motivation, time constraint, and adequate supervision in writing.

Considering the results of previous studies on L2 writing which showed that there are still many problems faced by L2 learners in EFL writing, teachers need to find a strategy to help students overcome the problems and promote students' writing ability, among others by involving students to foster social interaction and collaboration in discussing ideas and feedback in writing. One kind of social interaction is collaboration, and this has been proven useful in Donato's (1994) study, of which the results show that collaborating students can create the opportunity in exchanging and expanding the linguistics development among their peers. Another study by Fahim and Haghani (2012) investigates the socio-cultural perspectives on EFL setting and it shows that social interaction plays an important role in higher level of collaboration. Social interaction creates a good atmosphere to help the students to learn well by giving feedback to share the ideas to each other. Additionally, sociocultural theory in collaboration has been investigated by many researchers (Hosseinpour \& Biria, 2014; Lantolf \& Thorne, 2006; Storch, 2002, 2009; Widodo, 2013). In sum, social interaction and collaboration play important roles in that it emphasizes the value of learning from each other.

Collaborative writing allows students to share ideas and develop writing and social skills through interaction and with their peers (Fung, 2010; Storch, 2007; Swain \& Wanatabe, 2007). This is the manifestation of social learning theory which is rooted in Vygotsky's theory (1978), claiming that social interaction in learning is mediated by the students' experience in pairs and the context of learning. Students' life experience frequently affects their learning process where it can be implemented in sharing feedback among students so the students' life experience leads the student to be more critical in solving problem faced in learning. Moreover, the learning should be matched with the development level, which is called the zone of proximal development (ZPD). The concept of ZPD is important in collaboration because it is believed that when learners collaborate within their ZPD, they use their real knowledge to develop what they have not yet mastered independently (Aljaafreh \& Lantolf, 1994; Donato, 1994). ZPD emphasizes social interaction and collaboration and it can be in the form of pair work. A study by Storch (2011) has focused on the process, outcome, and future direction focused on pair work writing in the second language context. When students work in pair, they can exchange ideas and share feedback and this may result in students' being able to write better that when they write alone (Baleghizadeh, 2010; Wigglesworth \& Storch, 2009).

Numerous previous researchers in the area of second and foreign language have conducted studies on pair work writing. In the Indonesian context, Styati and Latief (2018) reported the study of pair work on writing performance based on the students' social interaction. Determining the member of the pair is based on mutuality - reciprocal feedback and sharing ideas, and equality - equal distribution and controlling the direction in discussion (Storch, 2002), which results in dominant and passive students. The result shows that the students write better in the dominant-dominant pairs (DDP) than in the dominant-passive pairs (DPP). Other study by Widodo (2013) found that collaborative activity in writing helps the EFL students in the classroom to write easily by using some stages such as prewriting up to post-writing. Moreover, Alfino (2017) conducted a study on the effect of pair work types (homogeneous, heterogeneous, and randomized pairs) on students' writing quality and the result shows that the randomized pair perform significantly better result than heterogeneous and homogenous pair. Furthermore, Fauziah and Latief (2015) investigated heterogeneous and homogeneous pairs on the students' writing skills and the result of the study reveals that the students' writing of heterogeneous pairs is more effective than that of homogenous pairs. Thus, the study of pair work writing can be classified based on many pair work types such as dominant-passive, heterogeneous, homogeneous, and randomized.

This research aimed to investigate the area of pair work and its possible benefits for L2 writing development based on theoretical models of social interaction as well as the area of proficiency by focusing on finding the effect of pair work writing based on social interaction and proficiency of the students. follows:

This study formulates the research questions as

1. Do the high proficient students engaging in the dominant-dominant pairs (H-DDP) 
write better than those engaging in the dominant-passive pairs (H-DPP)?

2. Do the low proficient students engaging in the dominant-dominant pairs (L-DDP) write better than those engaging in the dominant-passive pairs (L-DPP)?

\section{METHOD}

The study aims at investigating whether or not there is a significant difference in students' writing (1) between the high proficient students engaging in the dominant-dominant pairs (H-DDP) and those engaging in the dominant-passive pairs (H-DPP), and (2) between the low proficient students engaging in the dominant-dominant pairs (L-DDP) and those engaging in the dominant-passive pairs (L-DPP). Therefore, the experimental research was employed to answer the questions.

Two intact classes were chosen and assigned as group A and B. The students from these two groups were then classified into groups of students writing in pairs on the basis of social interaction (mutuality and equality) and proficiency. This social interaction refers to the theory of Storch (2002) which classifies students based on mutuality-reciprocal feedback and sharing ideas, and equality-equal distribution and controlling the direction in discussion so that the students were grouped into dominant and passive. Besides that, after being classified into dominant and passive groups, students were further classified based on their language proficiency so that they were grouped as high and low proficiency. This was to see the significant difference in the quality of writing between the two groups and to find out which group of students can do better at writing argumentative essays.

There were four procedures to form pair work. First, giving writing assignments to the students to discuss the topic of argumentative writing in pairs. Second, when the students were discussing in pairs, it was recorded, transcribed, and then analyzed. Third, their social interaction (mutuality-reciprocal feedback and sharing ideas, and equality-equal distribution and controlling the direction in discussion) was also analyzed using an observational instrument. Fourth, from the results of observations and transcribing, it was obtained the data on dominant and passive students. So, the pair was dominant-dominant pair (DDP) and dominantpassive pair (DPP).

After that they were paired again based on their language proficiency. They were categorized into high and low proficiency. The students' proficiency was measured from their writing on this topic: face-to-face communication was better than other types of communication, such as letters, email, or telephone calls (adopted from TOEFL writing section). This way, the pairs of high proficient students in the dominant-dominant pairs (H-DDP) and high proficient students in dominant-passive pairs (H-DPP) were formed. The other ones were the pair of low proficient students in the dominantdominant pairs (L-DDP) and the pair of low proficient students in dominant-passive pairs (LDPP). So, the first group was high dominantdominant pairs (H-DDP) and low dominantdominant pairs (L-DDP). The second group was high dominant-passive pairs (H-DPP) and low dominant-passive pairs (L-DPP).

The students were instructed to work together with their peers. The groups of high proficient students engaging in the dominant-dominant pairs (H-DDP) and high proficient students engaging in dominant-passive pairs (H-DPP) were compared. Then, the groups of low proficient students engaging in the dominant-dominant pairs (L-DDP) and low proficient students engaging in dominantpassive pairs (L-DPP) were also compared.

\section{Participants of the study}

There were forty-eight participants involved in this study and they were in the fourth semester in one of the English Education Departments at a private University in Madiun, East Java, Indonesia. The participants were selected because they have completed grammar courses such as intermediate and advanced grammar in the previous semester as well as writing paragraphs and essays courses so students are considered to have adequate experience in writing various types of paragraphs and essays. This is also to fill the gap in the previous study by Styati and Latief (2018) which recommends modification in pairwork by comparing the writing of the two groups of high and low-proficient students working on dominant-dominant pairs (DDP) and those working in dominant-passive pairs (DPP).

The two groups were formed in a pair work based on the students' social interaction and proficiency. Social interaction was determined on the basis of mutuality-reciprocal feedback and sharing ideas, and equality-equal distribution and controlling the direction in discussion. Mutuality refers to the interaction which is rich in reciprocal feedback and sharing ideas and equality refers to equal chance and control the direction on giving or exchanging the ideas (Storch, 2002).

Thus, the participants of the study were high proficient students engaging in dominant-dominant pair (H-DDP) and dominant-passive pair (H-DPP) and the low proficient students engaging in dominant-dominant pair (L-DDP) and dominantpassive pair (L-DPP).

\section{Research instruments}

The instrument used in this study was a writing test taken from the TOEFL writing section with the topic of communication and technology. This is a standardized writing proficiency test so that it does 
not require validation by experts and it can be directly used and given for the pretest and posttest. Meanwhile, the students' essay was measured against a scoring rubric consisting of five aspects: content, organization, vocabulary, grammar, and mechanics. The rubric was constructed based on the criteria of measuring the students' writing on an argumentative essay.

The writing rubric as a guideline for assessing students' writing skills was validated by two experts, professional lecturers of writing subjects with the same educational background and experienced in writing classes for about eleven years. To avoid absolute judgments and to maintain the consistency of the raters in measuring the students' writing, inter-rater reliability was established by inviting two raters and giving them a short training on scoring procedures and criteria. The reliability of the scores of the two raters was then measured using Pearson Product Moment Correlation (PPMC).

\section{Data collection}

A writing test in the form of an argumentative essay was administered to collect the data. It was given in the pretest to see whether the two groups were homogeneous and was used in posttest to see which one of the two groups showing significantly different mean score on the students' argumentative essay writing.

An argumentative essay writing test was administered to both groups in this study. It was given to the students working in dominant-dominant pairs (DDP) and dominant-passive pairs (DPP). The students were asked to write a three-paragraph argumentative essay. The essay consisted of three parts namely introduction, body, and concluding paragraphs. The students' argumentative essay writing was measured based on the scoring rubrics consisting of content, organization, vocabulary, grammar, and mechanic. The score ranged from 1 , 2 , 3, and 4 and each aspect of the rubric has a different weight so the weight for content, organization, vocabulary, grammar, and mechanics are $7,6,5,4$, and 3 , respectively. If the weight was multiplied by the range $1,2,3$, and 4 then the maximum overall score was 100 and the minimum score was 25 . The use of this analytic rubrics was to identify and assess components of writing and it was also based on preliminary studies on the development of a writing rubric with a scale of 4 , which was validated by the experts where each criterion has its own value with a different weight by considering the order of the most important components.

The data on the students' scores of argumentative essays were obtained from the high proficient students engaging in dominant-dominant pairs (H-DDP) and the high proficient students engaging in dominant-passive pairs (H-DPP), as well as from the low proficient students engaging in dominant-dominant pairs (L-DDP) and the low proficient students engaging in dominant-passive pairs (L-DPP). The students' writings were then scored and analyzed by using a statistical computer of SPSS 18.0 version.

\section{Data analysis}

An independent t-test was used to see if there was a significant difference in the mean scores of high proficient students involved in dominant-dominant pairs (H-DDP) and dominant-passive pairs (HDPP). Then, it was also used to see if there was a significant difference in the mean scores of low proficient students who were involved in the dominant-dominant interaction pairs. In addition, this study also used descriptive and inferential statistics to answer the investigations. Descriptive statistics provided maximum, minimum, mean, median, range and standard deviation, while inferential statistics was used to show probabilities and compare sample means from the population. Descriptive and inferential statistics were performed using SPSS version 18.0. Furthermore, when all these assumptions were determined, parametric statistical analysis was selected to test the hypothesis.

\section{FINDINGS}

Before presenting the main results of the research questions, the following is the result of the descriptive statistics, which describes the results of the posttest of both of the groups. Since the pretest scores showed that the groups were homogenous, then only the posttest scores were analyzed. Table 1 displays the descriptive data of the posttest scores of high proficient students engaging in the dominantdominant pairs (H-DDP) and those engaging in the dominant-passive pairs (H-DPP). Table 2 presents the descriptive data of the posttest scores of the low proficient students engaging in the dominantdominant pairs (L-DDP) and the dominant-passive pairs (L-DPP). Table 3 shows the results of group statistics of high proficient students working in DDP and DPP. Table 4 shows the results of independent t-test of high proficient students working in DDP and DPP. Table 5 shows the results of group statistics of low proficient students working in DDP and DPP. Table 6 shows the results of independent t-test of low proficient students working in DDP and DPP.

Table 1 indicates the essay writing scores obtained by 14 high proficient students engaging in the dominant-dominant pairs (H-DDP). The mean score is 84 , with 88 as the highest score and 75 the lowest score. Thus, the range between the highest and lowest score is 13 . Then, the standard deviation is 4.17 meaning that the students gain almost the same scores. Meanwhile, 11 high proficient students engaging in the dominant-passive pairs (H-DPP) 
obtained the mean score of 80 . The highest score is 88 and the lowest score is 70 so the range between the highest and lowest scores is 15 . Then, the standard deviation is 6.08 , which means the students gain varying scores. Furthermore, it is found that students in H-DDP gained better essay writing because the mean score obtained by students is higher than the students in H-DPP. The difference of the means of score both groups is 4 .

Table 2 presents the descriptive data of the posttest scores of the low proficient students engaging in the dominant-dominant pairs (L-DDP) and the dominant-passive pairs (L-DPP).

Table 1

Descriptive Statistics of the Students Engaging in H-DDP and H-DPP

\begin{tabular}{lcccccc}
\hline & N & Range & Min & Max & Mean & Std. Deviation \\
\hline H-DDP & 14 & 13 & 75 & 88 & 84 & 4.17 \\
H-DPP & 11 & 18 & 70 & 88 & 80 & 6.08 \\
\hline
\end{tabular}

Table 2

Descriptive Statistics of the Students Engaging in L-DDP and L-DPP

\begin{tabular}{ccccccc}
\hline & N & Range & Min & Max & Mean & Std. Deviation \\
\hline L-DDP & 10 & 17 & 74 & 91 & 81 & 4.84 \\
L-DPP & 13 & 11 & 75 & 86 & 80 & 3.73 \\
\hline
\end{tabular}

Table 2 displays the scores obtained by 10 low proficient students engaging in the dominantdominant pairs (L-DDP) in writing an essay. The mean score is 81 . The maximum score is 91 and the minimum score obtained by students is 74 . Thus, the range between the highest and lowest score is 17 . Then, the spread of deviation is 4.84. Meanwhile, 11 low proficient students engaging in the dominantpassive pairs (L-DPP) obtained the mean score of 80 . The highest score is 86 and the lowest score is 75 so that the range between the highest and lowest scores is 11 . The standar deviation is 3.73 which means the students gain almost the same scores. Furthermore, it is found that students in L-DDP produced better essay writing because the mean score obtained by students is higher than the students in H-DPP. It can be inferred that both groups gained almost the same mean scores. It can be seen in the difference of the mean of the DDP and DPP is 1.00 .

The Table 3 shows the result of the analysis to check whether there is significant difference in the mean scores obtained by the high proficient students engaging in the dominant-dominant pairs (H-DDP) and those engaging in the dominant-passive pairs (H-DPP), as well as the difference between the mean scores of low proficient students engaging in the dominant-dominant pairs (L-DDP) and the dominant-passive pairs (L-DPP).

Since the data of the two groups are homogeneous, parametric test on independent t-test is used to see the difference of the mean scores of both groups. The result is Table 3 .

Table 3

Results of Group Statistics of High Proficient Students Engaging in DDP and DPP

\begin{tabular}{lccccc}
\multicolumn{5}{c}{ Results of Group Statistics of High Proficient Students Engaging in DDP and DPP } \\
\hline H-DPP & H-DPP & N & Mean & Std. Deviation & Std. Error Mean \\
& 1.00 & 14 & 84 & 4.17 & 1.11 \\
\hline
\end{tabular}

The data from Table 3 indicate that the samples are 14 students for the H-DDP group and 11 students for the H-DPP $(\mathrm{N}=14$ of H-DDP and $\mathrm{N}=11$ of H-DPP). The mean score of high proficient students engaging in the dominant-dominant pair (H-DDP) is 84 while the mean score of the high proficient students engaging in dominant-passive

pair (H-DPP) is 80. This means that there is a significant difference in the mean scores of the argumentative essay writing obtained by the high proficient students engaging in the dominantdominant pair (H-DDP) and those engaging in the dominant-passive pair (H-DPP).

Table 4

Results of Independent t-test of High Proficient Students Engaging in DDP and DPP

\begin{tabular}{cllccccc}
\hline & & \multicolumn{3}{c}{$\begin{array}{c}\text { Lavene's Test for } \\
\text { Equality of Variances }\end{array}$} & \multicolumn{3}{c}{ t-test for Equality of Means } \\
\hline & & & F & Sig. & T & df & Sig. (2-tailed) \\
\hline VAR00001 & $\begin{array}{l}\text { Equal } \\
\text { assumed }\end{array}$ & variances & .968 & .335 & 2.153 & 23 & .042 \\
\hline
\end{tabular}

Table 4 depicts the result of the independent sample t-test of posttest of both groups of high proficient students working in the dominantdominant pairs (H-DDP) and the high proficient 
students working in the dominant-passive pairs $(\mathrm{H}-$ DPP). It is used to test the significant difference of the two groups. The result of sig. is .042, which can be seen from the Levene's test for equality of variances. It indicates that the result is lower than the significance level of .05, which means that there is a significant difference in both groups of high proficient students engaging in the dominantdominant pairs (H-DDP) and the high proficient students engaging in the dominant-passive pairs $(\mathrm{H}-$ DPP). Thus, HO can be rejected. The complete result can be seen in the Appendix 1.

Table 5

Results of Group Statistics of Low Proficient Students Engaging in DDP and DPP

\begin{tabular}{lccccc}
\hline & L-DPP & N & Mean & Std. Deviation & Std. Error Mean \\
\hline L-DDP & 1.00 & 10 & 81 & 4.84 & 1.53 \\
& 2.00 & 13 & 80 & 3.73 & 1.03 \\
\hline
\end{tabular}

Table 5 displays that the samples are 10 students for the L-DDP and 13 students for the LDPP ( $\mathrm{N}=10$ of L-DDP and $\mathrm{N}=13$ of L-DPP). Meanwhile, the means of both groups are not significantly different, in which the means of the low proficient students working in the dominantdominant pair (L-DDP) is 81 and the means of the

Table 6

Results of Independent t-test of Low Proficient Students Engaging in DDP and DPP

\begin{tabular}{|c|c|c|c|c|c|c|c|}
\hline & & & \multicolumn{2}{|c|}{$\begin{array}{c}\text { Lavene's Test for } \\
\text { Equality of Variances }\end{array}$} & \multicolumn{3}{|c|}{ t-test for Equality of Means } \\
\hline & & & $\mathbf{F}$ & Sig. & $\mathbf{T}$ & df & Sig. (2-tailed) \\
\hline VAR00001 & $\begin{array}{l}\text { Equal } \\
\text { assumed }\end{array}$ & variances & .231 & .636 & .293 & 21 & .772 \\
\hline
\end{tabular}

Table 6 displays the result of the independent sample t-test of posttest of both groups of low proficient students working in the dominantdominant pairs (L-DDP) and the low proficient students engaging in the dominant-passive pairs (LDPP). It is used to test the significant difference of the two groups of low proficient students engaging in the dominant-dominant pairs (L-DDP) and the low proficient students engaging in the dominantpassive pairs (L-DPP). The result of significance value obtained is .772 which is higher than the level of significance .05 . It can be perceived from the ttest for equality of mean that the result exceeds the level significance of .05 . This means there is no significant difference in both groups of low proficient students engaging in the dominantdominant pairs (L-DDP) and the low proficient students engaging in the dominant-passive pairs (LDPP). Thus, HO cannot be rejected. The complete result can be seen in the Appendix 2.

Table 7 shows the results of the descriptive statistics on aspects of writing for the students grouped in high and low proficiency in the dominant-dominant pairs (DDP) and dominant passive pairs (DPP) and it indicated a difference in the students' mean score.It can be seen that the HDDP students gain the highest mean score in almost all aspects except mechanics, while the L-DDP students gain higher mean score compared to L-DPP low proficient students engaging in the dominantpassive pair (L-DPP) is 80 . This indicates that there is no significant difference in the mean scores of the essay writing obtained by the low proficient students engaging in the dominant-dominant pair (L-DDP) and those engaging in the dominant-passive pair (LDPP). students in all aspects except in the aspect of content and grammar.

\section{DISCUSSION}

This study aims at investigating whether or not there is a significant difference in students' writing (1) between the high proficient students engaging in the dominant-dominant pairs (H-DDP) and those engaging in the dominant-passive pairs (H-DPP), and (2) between the low proficient students engaging in the dominant-dominant pairs (L-DDP) and those engaging in the dominant-passive pairs (L-DPP). This section gives detailed discussion and interpretation of the findings.

The high proficient students in the dominantdominant pairs (H-DDP) gained better scores in argumentative essay on the aspects of content, organization, vocabulary, and grammar than the high proficiency students in the dominant-passive pairs (H-DPP). It is supported by the data that the score of the content $(26.50>24.82)$, organization $(19.71>19.09)$, vocabulary $(15.36>14.09)$ and grammar $(13.43>12.73)$.

Regardless of the pair work type, this result shows that interaction in a collaborative writing affects the quality of students' writing. This is in line with the result of a study conducted by Elola and Oskoz (2012) in which all participants involved in collaborative writing found their overall writing quality improved when working collaboratively. 
Table 7

Result of Descriptive Statistics on Aspects of Writing

\begin{tabular}{|c|c|c|c|c|c|c|c|c|c|}
\hline \multirow{7}{*}{$\begin{array}{c}\text { Scores_of } \\
\text { Content }\end{array}$} & & \multirow{3}{*}{$\begin{array}{l}\mathbf{N} \\
14\end{array}$} & \multirow{3}{*}{$\begin{array}{c}\text { Mean } \\
26.50\end{array}$} & \multirow{3}{*}{$\begin{array}{c}\text { Std. Dev } \\
2.981\end{array}$} & \multirow{3}{*}{$\begin{array}{c}\text { Std. Error } \\
.797\end{array}$} & \multicolumn{2}{|c|}{ 95\% Confidence Interval for Mean } & \multirow{2}{*}{ Min. } & \multirow{2}{*}{ Max } \\
\hline & & & & & & Lower Bound & Upper Bound & & \\
\hline & HDDP & & & & & 24.78 & 28.22 & 21 & 28 \\
\hline & HDPP & 11 & 24.82 & 3.656 & 1.102 & 22.36 & 27.27 & 21 & 28 \\
\hline & LDDP & 10 & 23.10 & 3.381 & 1.069 & 20.68 & 25.52 & 21 & 28 \\
\hline & LDPP & 13 & 24.23 & 3.632 & 1.007 & 22.04 & 26.43 & 21 & 28 \\
\hline & Total & 48 & 24.79 & 3.525 & .509 & 23.77 & 25.82 & 21 & 28 \\
\hline Scores_of & HDDP & 14 & 19.71 & 2.813 & .752 & 18.09 & 21.34 & 18 & 24 \\
\hline \multirow[t]{4}{*}{ Organization } & HDPP & 11 & 19.09 & 2.427 & .732 & 17.46 & 20.72 & 18 & 24 \\
\hline & LDDP & 10 & 19.20 & 2.530 & .800 & 17.39 & 21.01 & 18 & 24 \\
\hline & LDPP & 13 & 18.00 & .000 & .000 & 18.00 & 18.00 & 18 & 18 \\
\hline & Total & 48 & 19.00 & 2.260 & .326 & 18.34 & 19.66 & 18 & 24 \\
\hline Scores_of & HDDP & 14 & 15.36 & 1.336 & .357 & 14.59 & 16.13 & 15 & 20 \\
\hline \multirow[t]{4}{*}{ Vocabulary } & HDPP & 11 & 14.09 & 2.023 & .610 & 12.73 & 15.45 & 10 & 15 \\
\hline & LDDP & 10 & 16.00 & 2.108 & .667 & 14.49 & 17.51 & 15 & 20 \\
\hline & LDPP & 13 & 15.00 & .000 & .000 & 15.00 & 15.00 & 15 & 15 \\
\hline & Total & 48 & 15.10 & 1.627 & .235 & 14.63 & 15.58 & 10 & 20 \\
\hline Scores_of & HDDP & 14 & 13.43 & 1.989 & .532 & 12.28 & 14.58 & 12 & 16 \\
\hline \multirow[t]{4}{*}{ Grammar } & HDPP & 11 & 12.73 & 1.618 & .488 & 11.64 & 13.81 & 12 & 16 \\
\hline & LDDP & 10 & 13.60 & 2.066 & .653 & 12.12 & 15.08 & 12 & 16 \\
\hline & LDPP & 13 & 13.85 & 2.075 & .576 & 12.59 & 15.10 & 12 & 16 \\
\hline & Total & 48 & 13.42 & 1.933 & .279 & 12.86 & 13.98 & 12 & 16 \\
\hline Scores_of & HDDP & 14 & 9.00 & .000 & .000 & 9.00 & 9.00 & 9 & 9 \\
\hline \multirow[t]{4}{*}{ Mechanics } & HDPP & 11 & 9.00 & .000 & .000 & 9.00 & 9.00 & 9 & 9 \\
\hline & LDDP & 10 & 9.30 & .949 & .300 & 8.62 & 9.98 & 9 & 12 \\
\hline & LDPP & 13 & 9.00 & .000 & .000 & 9.00 & 9.00 & 9 & 9 \\
\hline & Total & 48 & 9.06 & .433 & .063 & 8.94 & 9.19 & 9 & 12 \\
\hline
\end{tabular}

It was also found that the mean score of students in H-DDP is higher that of those in H-DPP $(84>80)$. This might be caused by the intensity of their interaction during the writing process. In dominant-dominat pair, each member of the pair actively contributes in giving feedback to each other. As Storch (2005) maintains that it is easy for the students to produce more accurate text by giving assistance to each other so that the students tend to write more complex sentences. The interaction in the pairwork allows students to help each other, reflect on and work together in the L2 writing. Working together in pairs also also ensures equal opportunity in giving feedback, which, according to Biria and Jafari (2013), can enhance the overall quality especially in organization of the students' writing and production.

This study found that high proficient students working in dominant interaction pairs can improve quality of their writing by the use of more complex sentences. This can be seen in the sample of students's essay below:

\section{Sample essay of H-DDP students}

Some people believe that modern technology creates a single world culture. It happens because modern technology rapidly changes the world's living standards. There are modern technologies, such as internet, television, electronic media, means of transportation and others. People use them with realizing the impacts. In fact, modern technology has a great impact on the way people live nowadays.
First of all, electronic medias such as internet and email, have changed the way how people from different culture background live easily. We have a great opportunity to find out more information about the countries and its history. For example, as a student, we want to find America culture, we can search it on google. We do not need to get there in finding America culture. Also, people can share ideas, happiness and difficulties through this modern technology.

From the sample essay above, we can see that students are able to write complex sentences (e.g. It happens because.....; First of all, ...). This supports Dobao's (2012) study which found that students can write more complex sentences to produce more accurate text in collaborative writing. Other researchers, such as Pae (2011) and Nassaji and Tian (2010) also report that collaborative writing contributes to students' writing accuracy. This is, however, slightly different from Shehadeh (2011), who found that collaborative writing had an overall significant effect on students' L2 writing, especially on content, organization, vocabulary, but not on grammar and mechanics.

In addition to allowing the exchange of feedback and ideas, collaboration promotes social interaction which can lead to better learning. This is because students are encouraged to cooperate with their partners by co-constructing knowledge in doing the task and help each other (Baleghizadeh, 2009). This also prevents students from relying only on the teacher because they can get the feedback and 
suggestion from their peers (Pae, 2011). This activity is found to be enjoyable and contributing to their L2 learning (Shehadeh, 2011). Widodo (2013) also claims that high achievers are encouraged to be aware of their social responsibility to support others. Thus, a social interaction community (Hosseinpour \& Biria, 2014) in a positive learning climate is created. They can also give feedback on the aspects of writing such as grammar development of ideas (content), and the essay organization (Berg, 1999). They can also discuss how to arrange the written text and were encouraged to focus on developing, evaluating ideas and organizing the ideas to have better writing (Neuman \& Mcdonough, 2015).

The low proficient students working in dominant-dominant pairs (L-DDP) and dominantpassive pairs (L-DPP) do not seem to show significant difference in their mean score, as indicated in Table 5, that the mean score of the low proficient students working in the dominantdominant pair (L-DDP) is 81 and the mean score of the low proficient students engaging in the dominant-passive pair (L-DPP) is 80. The low proficient students in the dominant-dominant pairs have better scores in organization, vocabulary, and mechanics while the low proficient students in dominant passive pairs have better scores in content and grammar. It can be seen from the data on the scores of L-DDP and L-DPP in the following aspects: organization $(19.20>18.00)$, vocabulary $(16.00>15.00)$, and mechanics $(9.30>9.00)$. This may explain that only particular kind of interaction in the form of collaboration can succeed in the teaching learning process especially in writing (Donato, 1994). In this case, the levels of proficiency and interaction between students working in pairs determine the effectiveness of collaborative writing.

To sum up, there is a significant difference in students' writing (1) between the high proficient students engaging in the dominant-dominant pairs (H-DDP) and those engaging in the dominantpassive pairs (H-DPP), and (2) between the low proficient students engaging in the dominantdominant pairs (L-DDP) and those engaging in the dominant-passive pairs (L-DPP). The high proficient students engaging in the dominantdominant pairs can help their partners to produce argumentative writing text better on the aspects of content, organization, vocabulary and grammar. On the other hand, the low proficient students engaging in dominant-dominant pair (L-DDP) show better writing in argumentative essay in the aspects of organization, vocabulary, and mechanics, while the low proficient students in DPP can produce a good writing in terms of content and grammar.

\section{CONCLUSION}

This study shows that there is a significant difference in the mean scores of essay writing between the high proficient students engaging in the dominant-dominant pairs and those engaging in the dominant-passive pairs. The results indicate that the dominant students and the high proficient students in the dominant-dominant pairs write better in the aspects of content $(26.50>24.82)$, organization $(19.71>19.09)$, vocabulary $(15.36>14.09)$ and grammar $(13.43>12.73)$ in writing an argumentative essay than those engaging in the dominant-passive pairs. On the other hand, the investigation presents no significant difference in the mean scores of the argumentative essay writing betwen the low proficient students engaging in the dominantdominant pairs and those engaging in the dominantpassive pairs. It indicates that the students who have low proficiency in both of the groups (DDP and DPP) have relatively the same ability in writing an argumentative essay. Thus, this study reveals that the high proficient students engaging in dominantdominant pairs produce better writing in argumentative essay than the high proficient students working in dominant-passive pairs.

Further research on this topic needs to be conducted to find out what potential factors that cause the same result of the low proficient students engaging in dominant-dominant pairs and dominantpassive pairs. Further studies may also look into different method of classifying the students. It is also recommended to involve more subjects on the research to provide an in-depth study on this topic. In addition, this study is quantitative in nature so, it may fail to see in detail the aspects of students' essay which may have been affected by the treatment. Thus, a more qualitative study on this topic is highly recommended.

This study suggests that pair work can be an alternative in promoting students' collaboration in writing, provided that the teachers take into account the strand such as students' proficiency and level of interaction for the effectiveness of the pair work activity.

\section{ACKNOWLEDGMENTS}

We would like to acknowledge to the institution and participants who provide the valuable data in this study. My sincere thanks also go to Prof. Mohammad Adnan Latief, M.A., Ph.D, Prof. A. Effendi Kadarisman, Ph.D, and Dr. Suharmanto, M.Pd for their professional support and insightful feedback. We are grateful to the reviewers and editor of the manuscript. Directorate Higher Education of Indonesia.

\section{REFERENCES}

Adeyemi, D. A. (2012). Approaches to composition writing: The case of junior secondary schools in Botswana. International Journal of learning and Development, 2(1), 48-64. https://doi.org/10.5296/ijld.v2i1.1218 
Alfino, J. (2017). The effect of pair-work types on students' writing quality. [Unpublished Doctoral Dissertation] State University of Malang, Indonesia.

Aljaafreh, A., \& Lantolf, J.P. (1994). Negative feedback as regulation and second language learning in the zone of proximal development. The Modern Language Journal, 78(4), 465483. https://doi.org/10.1111/j.15404781.1994.tb02064.x

Barkaoui, K. (2007). Teaching writing to second language learners: Insights from theory and research. TESL Reporter, 40(1), 35-48. https://osf.io/preprints/socarxiv/h3b76/downlo ad

Baleghizadeh, S. (2009). Investigating the Effectiveness of pair work on a conversational cloze task in EFL classes. TESL Reporter, 42(2), 1-12. http://ojsdev.byuh.edu/index.php/Issue1/article/downloa d/1036/988

Baleghizadeh, S. (2010). The effect of pair work on a word-building task. ELT journal, 64(4), 405413. https://doi.org/10.1093/elt/ccp097

Berg, E. C. (1999). The effect of trained peer response on ESL students' revision types and writing quality. Journal of Second Language Writing, 8(3), 215-241. https://doi.org/10.1016/s1060-3743(99)801155

Biria, R., \& Jafari, S. (2013). The impact of collaborative writing on the writing fluency of Iranian EFL Learners. Journal of Language Teaching and Research, 4(1), 164- 175. https://www.academypublication.com/issues/p ast/jltr/vol04/01/22.pdf

Chen, Y. (2002). The problems of University EFL writing in Taiwan. The Korea TESOL Journal, 5(1), 59-79.

https://koreatesol.org/sites/default/files/pdf_pu blications/KTJ5-2002web.pdf

Dobao, A. F. (2012). Pair work writing tasks in the L2 classroom: Comparing group, pair, and individual work. Journal of Second Language Writing, 21(1), 40-58. https://doi.org/10.1016/j.jslw.2011.12.002

Donato, R. (1994). Collective scaffolding in second language learning. In J.P. Lantolf \& G. Appel (Eds.), Vygotskian approaches to second language research (pp.33-56). Albex.

Elola, I., \& Oskoz, A. (2010). Collaborative writing: Fostering foreign language and writing conventions development. Language Learning \& Technology, 14(3), 51-71. https://www.lltjournal.org/item/2700

Fahim, M., \& Haghani, M. (2012). Sociocultural perspectives on foreign language learning. Journal of Language Teaching and Research, 3(4), 693-699. http://www.academypublication.com/issues/pa st/jltr/vol03/04/14.pdf

Fauziah, H., \& Latief, M.A. (2015). The effect of working in heterogeneous and homogeneous pairs on the students' writing skill. Arab World English Journal (AWEJ), 6(2), 174-188. https://doi.org/10.24093/awej/vol6no2.14

Fung, Y. M. (2010). Collaborative writing features. RELC Journal, 41(1), 18-30. https://doi.org/10.1177/0033688210362610

Hosseinpour, N., \& Biria, R. (2014). Improving Iranian EFL learners'writing through taskbased collaboration. Theory and Practice in Language Studies, 4(11), 2428-2435. https://doi.org/10.4304/tpls.4.11.2428-2435

Lantof, J. P., \& Thorne, S. L. (2006). Sociocultral theory and the genesis of second language development. Oxford University Press.

Nassaji, H., \& J. Tian. (2010). Pair work and individual output tasks and their effects on learning English phrasal verbs. Language Teaching Research, 14(4), 397-419. https://doi.org/10.1177/1362168810375364

Neuman, H., \& McDonough, K. (2015). Exploring student interaction during collaborative prewriting discussions and its relationship to L2 writing. Journal of Second Language Writing, 27, 84-104. https://doi.org/10.1016/j.jslw.2014.09.009

Pae, J. K. (2011). Collaborative writing versus individual writing: Fluency, accuracy, complexity, and essay score. Multimedia Assisted Language Learning, 14(1), 121-148. https://doi.org/10.1016/j.jslw.2014.09.009

Shehadeh, A. (2011). Effects and student perceptions of collaborative writing in L2 effects and student perceptions of collaborative writing in L2. Journal of Second Language Writing, 20(4), 286-305. https://doi.org/10.1016/j.jslw.2011.05.010.

Storch, N. (2002). Patterns of interaction in ESL pair work. Language Learning, 52(1), 119158. https://doi.org/10.1111/1467-9922.00179

Storch, N. (2005). Collaborative writing: Product, process, and students' reflections. Journal of Second Language Writing, 14(3), 153-173. https://doi.org/10.1016/j.jslw.2005.05.002.

Storch, N. (2007). Investigating the merits of pair work on a text editing task in ESL classes. Language Teaching Research, 11(2), 143-159. https://doi.org/10.1177/136216880707460011.

Storch, N. (2009). The nature of pair interaction. learners' interaction in an ESL Class. Its nature and impact on grammatical development. VDM Verlag.

Storch, N. (2011). Collaborative writing in L2 contexts: Processes, outcomes, and future directions. Annual Review of Applied Linguistics, 31, 275-288. https://doi.org/10.1017/s0267190511000079 
Styati, E.W., \& Latief, M. A. (2018). Investigating dominant and passive students on pair work towards the students' writing performance. $3 L$ : Language, Linguistics, Literature $®, 24(3)$, 124-154. https://doi.org/10.17576/3L-20182403-11

Swain, M., \& Wanatabe, Y. (2007). Effects of proficiency differences and patterns of pair interaction on second language learning: Collaborative dialogue between adult ESL learners. Language Teaching Research, 11(2), 121-142.

https://doi.org/10.1177/136216880607074599
Vygotsky, L. S. (1978). Mind in society. The development of higher psychological processes. Harvard University Press.

Widodo, H. P. (2013). Implementing collaborative process based writing in the EFL college classroom. Research Papers in Language Teaching and Learning, 4(1), 198-206.

Wigglesworth, G., \& Storch, N. (2009). Pair versus individual writing: Effects on fluency, complexity and accuracy. Language Testing, 26(3), 445- 466. https://doi.org/10.1177/0265532209104670

\section{APPENDIXES}

\section{Appendix 1}

Results of t-test of High Proficient in DDP and DPP

\begin{tabular}{|c|c|c|c|c|c|c|c|c|c|c|}
\hline \multicolumn{11}{|c|}{ Independent Samples Test } \\
\hline & & \multicolumn{2}{|c|}{$\begin{array}{c}\text { Levene's Test for } \\
\text { Equality of } \\
\text { Variances }\end{array}$} & \multicolumn{7}{|c|}{ t-test for Equality of Means } \\
\hline & & \multirow[b]{2}{*}{$\mathrm{F}$} & \multirow[b]{2}{*}{ Sig. } & \multirow[b]{2}{*}{$\mathrm{t}$} & \multirow[b]{2}{*}{$\mathrm{df}$} & \multirow[b]{2}{*}{$\begin{array}{l}\text { Sig. (2- } \\
\text { tailed) }\end{array}$} & \multirow[b]{2}{*}{$\begin{array}{c}\text { Mean } \\
\text { Differenc } \\
\mathrm{e}\end{array}$} & \multirow[b]{2}{*}{$\begin{array}{c}\text { Std. Error } \\
\text { Differenc } \\
\mathrm{e}\end{array}$} & \multicolumn{2}{|c|}{$\begin{array}{l}95 \% \text { Confidence } \\
\text { Interval of the } \\
\text { Difference }\end{array}$} \\
\hline & & & & & & & & & Lower & Upper \\
\hline \multirow[t]{2}{*}{$\begin{array}{l}\text { VAROO } \\
001\end{array}$} & $\begin{array}{l}\text { Equal variances } \\
\text { assumed }\end{array}$ & .968 & .335 & 2.153 & 23 & .042 & 4.41558 & 2.05084 & .17311 & 8.65806 \\
\hline & $\begin{array}{l}\text { Equal variances } \\
\text { not assumed }\end{array}$ & & & 2.058 & 16.957 & .055 & 4.41558 & 2.14604 & -.11303 & 8.94420 \\
\hline
\end{tabular}

\section{Appendix 2}

Results of t-test of Low Proficient in DDP and DPP

\begin{tabular}{|c|c|c|c|c|c|c|c|c|c|c|}
\hline \multicolumn{11}{|c|}{ Independent Samples Test } \\
\hline & & \multicolumn{2}{|c|}{$\begin{array}{c}\text { Levene's Test for } \\
\text { Equality of } \\
\text { Variances }\end{array}$} & \multicolumn{7}{|c|}{ t-test for Equality of Means } \\
\hline & & \multirow[b]{2}{*}{$\mathrm{F}$} & \multirow[b]{2}{*}{ Sig. } & \multirow[b]{2}{*}{$\mathrm{t}$} & \multirow[b]{2}{*}{ df } & \multirow[b]{2}{*}{$\begin{array}{l}\text { Sig. (2- } \\
\text { tailed) }\end{array}$} & \multirow[b]{2}{*}{$\begin{array}{c}\text { Mean } \\
\text { Differenc } \\
\mathrm{e} \\
\end{array}$} & \multirow[b]{2}{*}{$\begin{array}{c}\text { Std. Error } \\
\text { Differenc } \\
\mathrm{e}\end{array}$} & \multicolumn{2}{|c|}{$\begin{array}{c}95 \% \text { Confidence } \\
\text { Interval of the } \\
\text { Difference }\end{array}$} \\
\hline & & & & & & & & & Lower & Upper \\
\hline \multirow[t]{2}{*}{$\begin{array}{l}\text { VAR00 } \\
001\end{array}$} & $\begin{array}{l}\text { Equal variances } \\
\text { assumed }\end{array}$ & .231 & .636 & .293 & 21 & .772 & .52308 & 1.78295 & -3.18477 & 4.23093 \\
\hline & $\begin{array}{l}\text { Equal variances } \\
\text { not assumed }\end{array}$ & & & .283 & 16.527 & .780 & .52308 & 1.84602 & -3.38019 & 4.42634 \\
\hline
\end{tabular}

